\title{
Invasive fish threat in Manyas Lake (Turkey)
}

\author{
Gülşah SAÇ *1, Özcan GAYGUSUZ ${ }^{1}$, Ali ERTÜRK ${ }^{1}$ \\ ORCID: 0000-0001-9988-1116; 0000-0001-6861-6221; 0000-0002-3532-2961
}

${ }^{1}$ Istanbul University, Faculty of Aquatic Sciences, Department of Marine and Freshwater Resources Management, 34134, Laleli, İstanbul, Turkey

\begin{abstract}
Two non-native freshwater fish species, Gambusia holbrooki Girard, 1859 and Pseudorasbora parva (Temminck \& Schlegel, 1846) were recorded for the first time for the Manyas Lake, and the number of the non-native fish species living in the lake has increased to three. These non-native fish species described as invasive were considered as new threats to the lake, which is already threatened by eutrophication and habitat degradation.
\end{abstract}

Key words: non-native species, shallow lake, biodiversity, Pseudorasbora parva, Gambusia holbrooki

\section{Manyas Gölü (Türkiye)'nde istilacı balık tehdidi}

\section{Özet}

Yerli olmayan iki tatlısu balığı türü, Gambusia holbrooki Girard, 1859 ve Pseudorasbora parva (Temminck \& Schlegel, 1846) Manyas Gölü için ilk kez kaydedilmiştir ve gölde yaşayan egzotik balıkların sayısı üçe yükselmiştir. İstilacı olarak tanımlanan bu egzotik balıklar, ötrofikasyon ve habitat tahribatı tehdidi de olan göl için yeni tehditler olarak tanımlanmıştır.

Anahtar kelimeler: yabancı tür, sığ göl, biyoçeşitlilik, Pseudorasbora parva, Gambusia holbrooki

\section{Introduction}

The intentional introduction of fish around the world is mostly the consequence of the globalization of the aquaculture trade and the increase of the societal demands such as angling or sport fishing, filling an ecological niche as food, foraging for fisheries, biological control, and ornamental fish [1, 2]. After a non-native species is introduced to a new ecosystem, if it adapts well in the environment, and reproduces and spreads rapidly, it may become an invasive that will damage the ecosystem processes [3]. Introduction and spreading of invasive fish have been evaluated as a global problem due to their both ecological and economical risks and the investigation of the effects of these fishes has constituted an exponentially growing attention among the scientific literature since the 1970s [2, 4]. With a general view that non-native fish introduction is considered as a major threat to local fish populations and biodiversity in aquatic ecosystems in general via mechanisms such as out-competition (food or habitat), hybridization, the transmission of a novel disease and predation when they became highly abundant $[4,5,6]$. One of the most striking examples of the impacts of an introduced fish is Nile perch Lates niloticus (Linnaeus, 1758), a large piscivorous, which caused destruction in Lake Victoria and its surroundings. The fish was introduced with the aim of recreational fishing to the lake, where is considered to have the richest fish fauna in the world, and it has become the dominant species over time and then has caused the extinction of the many herbivores endemic and native Cichlid species. As the herbivore fish disappeared, the food web in the lake has severely altered and the excessive algae increase has caused oxygen depletion in the bottom. The impact of the fish was not limited to the lake, it has led to socioeconomic changes and environmental damage as well. The increase in the population density of the fish has directed many families to the fisheries and as a result of the excessive human migration to the surrounding of the lake, fishery- related employment has approximately doubled. The fish, which were harvested in large quantities, have started to be released to the

\footnotetext{
${ }^{*}$ Corresponding author / Haberleşmeden sorumlu yazar: Tel.: +905553512569; Fax.: +905553512569; E-mail: gulsahsac@ gmail.com

(C) Copyright 2020 by Biological Diversity and Conservation $\quad$ Received: 06.01.2020; Published: 15.08.2020 
market with the smoking process. Trees cut for these purposes caused landslides on the hills around Lake Victoria, and therefore, large amounts of silt have entered into the lake [3, 7, 8].

The Manyas Lake located at the Susurluk river basin in northwest Anatolia is one of the most important shallow lakes in Turkey. Susurluk river basin is one of Turkey's 25 main watersheds by the hydrological properties [9]. While the lake gets most of its water from Kocaçay, Sığırcı and Mürvetler streams and groundwater, the outlet water of the lake is Karadere connected to the Susurluk River. This special lake, which has the status of wetland, was designated as Ramsar Site in 1994 in terms of being at migration routes of some bird species and used by these birds as a nesting and shelter area [10]. The lake, from the past to the present, has been also a valuable fish production area that has favourable ecological conditions for fish to survive, and fishing activities are evaluated as an important income for the local people [11]. Previous studies reported 23 fish species living in the Manyas lake basin as follows; Alburnus carinatus Battalgil, 1941, Alburnoides manyasensis Turan, Ekmekçi, Kaya \& Güçlü, 2013, Alosa maeotica (Grimm, 1901), Barbus niluferensis Turan, Kottelat \& Ekmekçi, 2009, Blicca bjoerkna (Linnaeus, 1758), Capoeta tinca (Heckel, 1843), Cobitis puncticulata Erk'akan, Atalay-Ekmekçi \& Nalbant, 1998, Cyprinus carpio (Linnaeus, 1758), Carassius carassius (Linnaeus, 1758), Carassius gibelio (Bloch, 1782), Esox lucius (Linnaeus, 1758), Knipowitschia longicaudata (Kessler, 1877), Leuciscus aspius (Linnaeus, 1758), Neogobius fluviatilis (Pallas, 1814), Oxynoemacheilus simavicus (Balık \& Bănărescu, 1978), Petroleuciscus borysthenicus (Kessler, 1859), Proterorhinus semilunaris (Heckel, 1839), Rhodeus amarus (Bloch, 1782), Rutilus rutilus (Linnaeus, 1758), Scardinius erythrophthalmus (Linnaeus, 1758), Silurus glanis (Linnaeus, 1758) Squalius cii (Richardson, 1857) and Vimba vimba (Linnaeus, 1758) $[12,13,14,15]$. Five of them (A. carinatus, A. manyasensis, B. niluferensis, O. simavicus, and $S$. cii) are cited as endemic fish species for western Anatolia and this biological richness further increases the importance of the lake basin.

Over the last years, the Manyas Lake has become more and more polluted due to eutrophication, habitat degradation, and environmental pressures such as agriculture, poultry husbandry, and industrial facilities, and its ecological function was threatened by these negative effects $[16,17]$. Besides the decrease in the lake's ecosystem services and processing, non-native and/or invasive fish species may become direct threats. They may have a detrimental impact on the sustainability of fish diversity and their biomass as well as local fisheries and may cause irreversible damages especially for the future of endemic fishes. The first non-native fish species reported for the lake is C. gibelio but as an invasive species, there have been no studies on its possible impacts on the fish fauna since the 2000s when it was reported [18]. This study aims to report the presence of the other non-native fish species that may pose a threat to the biodiversity in the Manyas Lake and to list possible invasion threats to the future of the native and endemic fishes in the lake.

\section{Materials and methods}

Fish samples were collected using a portable electro-shocker (SAMUS 725G), cast-nets (10 mm mesh-sized) and a scoop-net (2 mm mesh-sized) from the shorelines of the Manyas Lake (Figure 1) between April and August 2019. The fish samplings were conducted near Bird Paradise National Park with a coordinate $40.225561^{\circ} \mathrm{N}, 28.049675^{\circ} \mathrm{E}$.

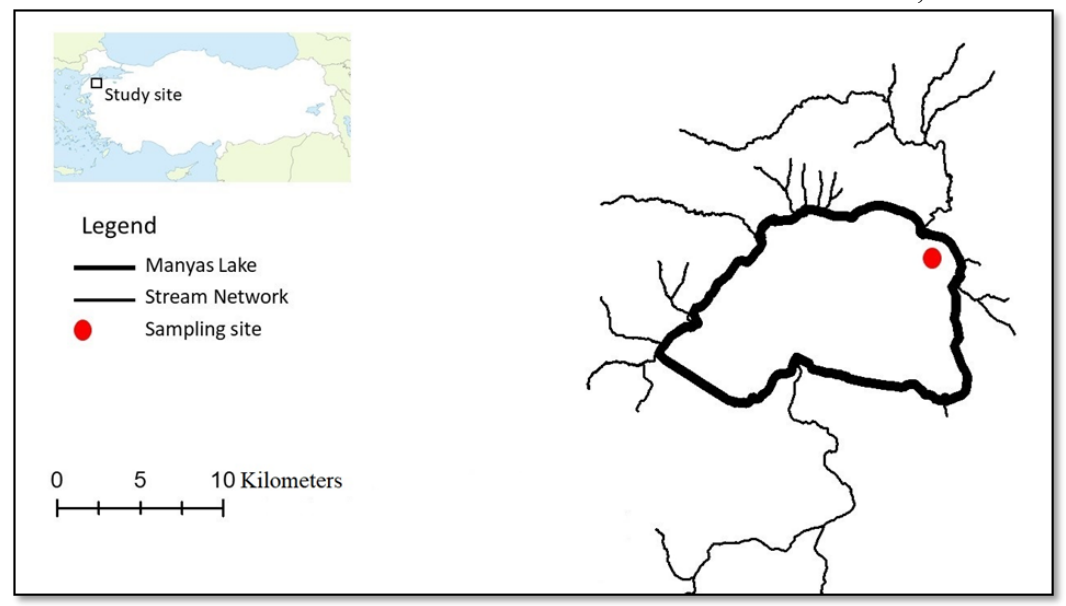

Figure 1. The sampling area in the Manyas Lake

The fish specimens were killed with an overdose anaesthesia (clove oil) and then immediately transferred to the Laboratory of Istanbul University Faculty of Aquatic Sciences Department Freshwater Resources and Management with cold conditions. The fish samples were measured for total length (TL) to the nearest $0.1 \mathrm{~cm}$ and weighed for total body weight (W) on a digital balance with a $0.01 \mathrm{~g}$ accuracy.

\section{Results}

During the routine ichthyological surveys in the Manyas Lake, three non-native species, C. gibelio, Gambusia holbrooki Girard, 1859 and Pseudorasbora parva (Temminck \& Schlegel, 1846), and nine native fishes (A. carinatus, B. bjoerkna, C. puncticulata, K. longicaudata, N. fluviatilis, $R$. rutilus, S. erythrophthalmus, $R$. amarus, and P. semilunaris) were caught. Gambusia holbrooki and P. parva were recorded for the first time for the Manyas Lake (Figure 2, Figure 3). The individual numbers, body size, and weight distributions and sampling dates of these fishes were listed in Table 1. 
Table 1. The individual numbers (n), length (TL) and weight (W) distributions, and sampling dates of fishes caught in the Manyas Lake (a: electro-shocker, b: cast-net, c: scoop-net)

\begin{tabular}{|c|c|c|c|c|}
\hline Fish Species & $\mathbf{n}$ & $\begin{array}{l}\text { TL, cm } \\
\text { min - max }\end{array}$ & $\begin{array}{l}\mathrm{W}, \mathbf{g} \\
\mathbf{m i n}-\max \end{array}$ & $\begin{array}{l}\text { Sampling } \\
\text { Dates }\end{array}$ \\
\hline Carassius gibelio $^{\mathrm{a}, \mathrm{b}}$ & 56 & $4.3-13.1$ & $1.68-38.54$ & $\begin{array}{l}\text { 12.06.2019; } \\
\text { 24.07.2019; } \\
21.08 .2019\end{array}$ \\
\hline Gambusia holbrooki $^{\text {b, c }}$ & 95 & $1.7-3.5$ & $0.04-0.72$ & $\begin{array}{l}24.07 .2019 \\
21.08 .2019\end{array}$ \\
\hline Pseudorasbora parva ${ }^{\text {a, b }}$ & 25 & $2.6-9.9$ & $0.15-11.15$ & $\begin{array}{l}18.04 .2019 ; \\
21.08 .2019\end{array}$ \\
\hline Alburnus carinatus ${ }^{\mathrm{a}}$ & 60 & $9.0-11.9$ & $12.45-32.03$ & $\begin{array}{l}\text { 18.04.2019; } \\
\text { 16.05.2019; } \\
\text { 12.06.2019; } \\
\text { 24.07.2019 }\end{array}$ \\
\hline Blicca bjoerkna ${ }^{\mathrm{a}}$ & 85 & $9.6-23.1$ & $9.13-159.29$ & $\begin{array}{l}18.04 .2019 ; \\
16.05 .2019 ; \\
\text { 12.06.2019; } \\
24.07 .2019 ; \\
21.08 .2019\end{array}$ \\
\hline Cobitis puncticulata ${ }^{\mathrm{b}}$ & 1 & 3.7 & 0.51 & 21.08 .2019 \\
\hline Knipowitschia longicaudata ${ }^{\mathrm{b}}$ & 22 & $2.5-3.4$ & $0.11-0.38$ & 21.08 .2019 \\
\hline Neogobius fluviatilis ${ }^{\mathrm{a}, \mathrm{b}}$ & 17 & $8.9-15.4$ & $8.54-47.44$ & $\begin{array}{l}\text { 18.04.2019; } \\
\text { 16.05.2019; } \\
12.06 .2019\end{array}$ \\
\hline Rutilus rutilus $^{\text {a }}$ & 78 & $9.5-21.1$ & $8.83-117.58$ & $\begin{array}{l}\text { 18.04.2019; } \\
\text { 16.05.2019; } \\
\text { 12.06.2019; } \\
\text { 24.07.2019; } \\
21.08 .2019\end{array}$ \\
\hline Scardinius erythrophthalmus ${ }^{\mathrm{a}, \mathrm{b}}$ & 21 & $4.4-21.7$ & $0.86-132.51$ & $\begin{array}{l}\text { 18.04.2019; } \\
\text { 24.07.2019; } \\
21.08 .2019\end{array}$ \\
\hline Rhodeus amarus ${ }^{\mathrm{b}}$ & 43 & $2.1-3.9$ & $0.09-2.90$ & 21.08 .2019 \\
\hline Proterorhinus semilunaris ${ }^{\mathrm{b}, \mathrm{c}}$ & 10 & $2.7-4.4$ & $0.18-0.93$ & 21.08 .2019 \\
\hline
\end{tabular}

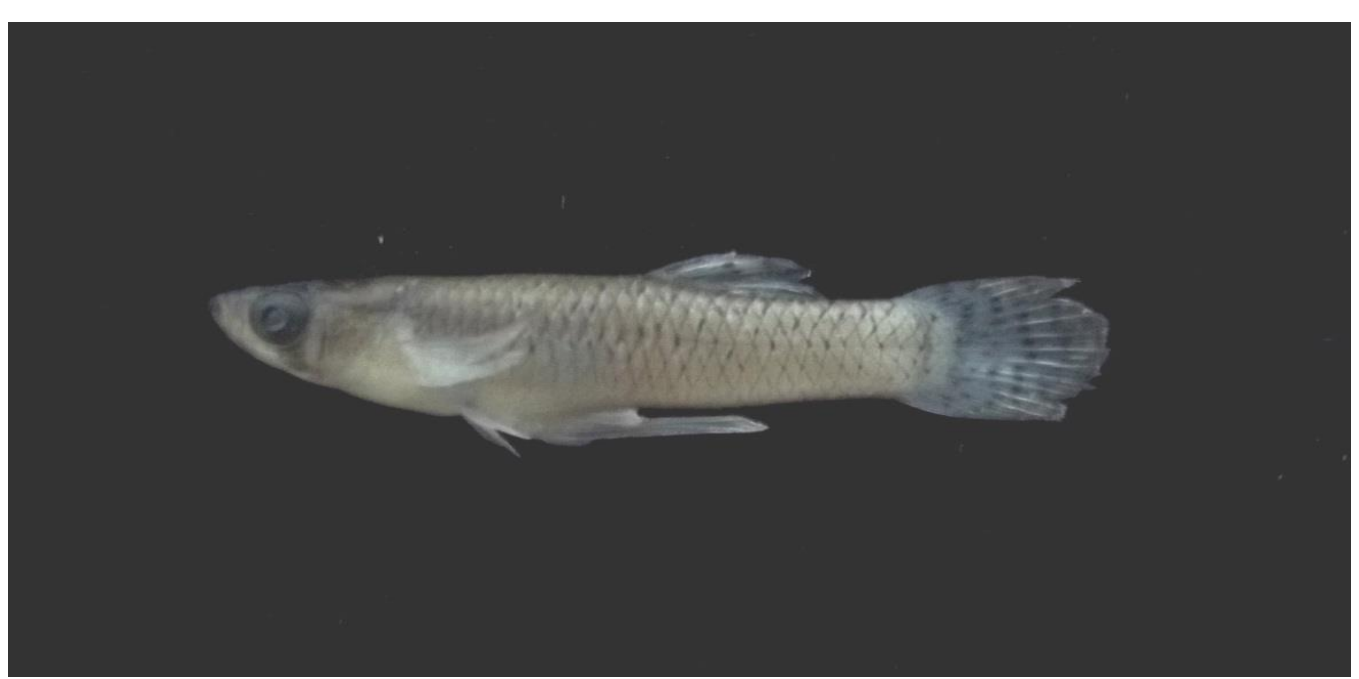

Figure 2. Gambusia holbrooki Girard, 1859, male, 2.9 cm TL, Manyas Lake, 2019 


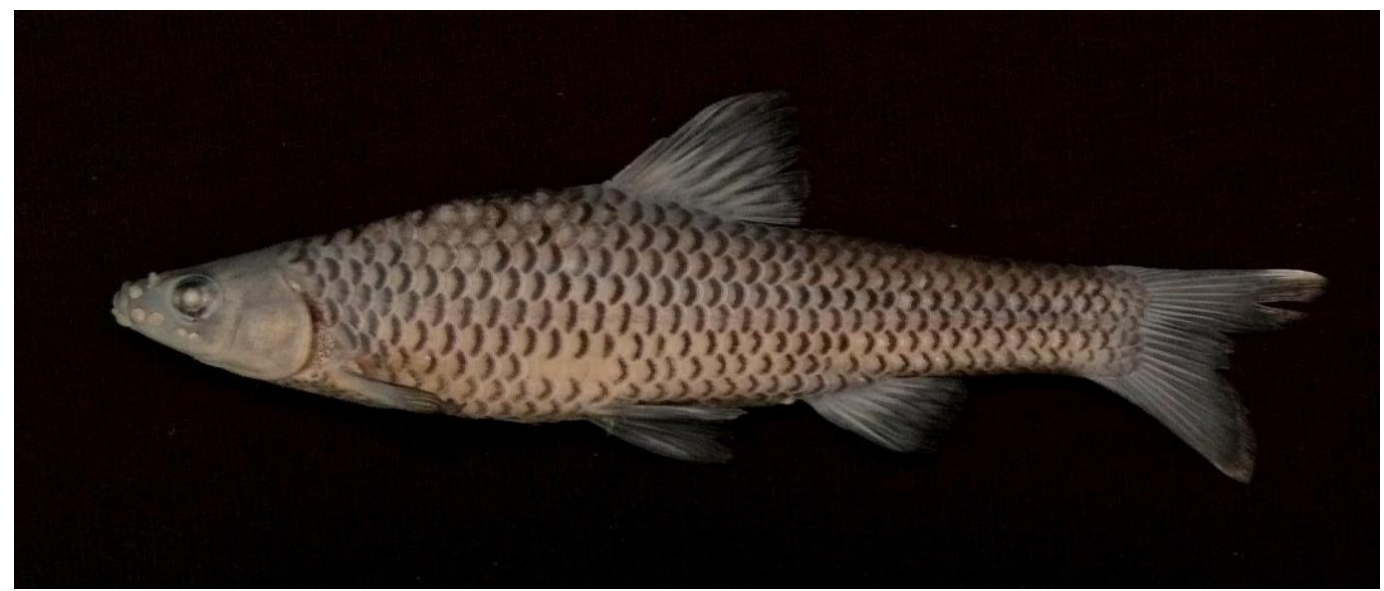

Figure 3. Pseudorasbora parva (Temminck \& Schlegel, 1846), male, $8.0 \mathrm{~cm}$ TL, Manyas Lake, 2019

\section{Conclusions and discussion}

In order to obtain the safe withdrawal amount from fish stocks within sustainable limits, it is important to quantify the fish populations, especially their species and size compositions, at intervals. The contribution of the Manyas Lake, which provides valuable ecosystem services as a lake-wetland complex, to local fisheries is also very important. Therefore, it is critical to monitor the dynamics of the lake in order to obtain a sustainable maximum efficiency from the lake.

The presence of invasive C. gibelio in the Manyas Lake was already reported in the 2000s [18], but the other invasive fishes, G. holbrooki and P. parva were notified for the first time with this study. With these invasive fish records, a new one has been added to the threats for the future of the lake. According to the information from the local fishermen, C. gibelio has rapidly increased the size of the population after introduction into the lake and became one of the most intensively hunted fish species. However, nowadays it is postulated that the population density of this invasive fish has decreased with the excessive fishing pressure on it.

In this study, the use of different fishing gear allowed different fish species to be caught: invasive $C$. gibelio and $P$. parva were caught with electro-shocker and cast-nets, while G. holbrooki was caught with electro-shocker and scoop-net (Table 1). Failure to catch some of the previously reported fishes (such as B. niluferensis, O. simavicus, and A. bipunctatus) from the lake basin is related to the fact that these species mostly prefer the streams. Catch per unit effort (CPUE) values of fishes were not calculated because they were caught with three different fishing equipment. Although their abundance cannot be calculated, the individual numbers and size ranges of both endemic and native fishes of the lake are quite satisfactory (Table 1). Unfortunately, the catch of the individuals of the two new invasive species in different size ranges (P. parva, $2.6-9.9 \mathrm{~cm}, \mathrm{TL} ; G$. holbrooki, $1.7-3.5 \mathrm{~cm}$, TL) indicates that they have successfully reproduced and colonized in this lake.

Small bodied G. holbrooki is originally native to the coastal regions of south-eastern United-States and it has been intentionally or accidentally introduced throughout worldwide especially the warm temperate and tropical regions $[19,20]$. Intentional introductions of this mosquitofish were undertaken for using it as a biological control agent for the prevention of malaria threats $[21,22]$. Some features of this species such as having a high level of plasticity and survival capability, colonizing easily to new habitats, withstanding wide ranges of temperature and salinity and surviving in heavily polluted waters are effective in spreading through wide areas [23, 24]. According to the Global Invasive Species Program (GISP), G. holbrooki is one of the world's 100 worst invasive alien species [25]. There are some records that confirm its negative effects and predatory behaviour on many native fish, amphibians and invertebrates; such as eating the eggs and larvae of fishes or amphibians and competing with native fishes for food resources through niche overlap [26, 27]. Rincón et al. [28] mentioned that G. holbrooki had an impact on seriously threatening endemic species, most notably Aphanius and Valencia species, in Europe. Similarly, it is thought that this invasive fish, which reproduces several times a year, may increase its population size and can create pressure on native and endemic fish species living in Manyas Lake with food and habitat competition.

The topmouth gudgeon $P$. parva, a small freshwater species originating from East Asia (Japan, China, Korea, and the River Amur), is an invasive species that was introduced to many countries in different continentals accidentally [29]. The primary pathway of $P$. parva introduction into its expanded range is the accidental transfer and release of this fish within the translocations of native fishes for aquaculture activities [30]. The most remarkable threat of this fish, showing a rapid colonization success in new habitats, is to carry non-native pathogens for native fauna besides the risk of food and space competition [29]. Pseudorasbora parva is a healthy carrier of the rosette agent Sphareothecum destruens that is a fungal disease and a potential threat to native fish biodiversity [31, 32]. This agent was first identified in Europe in 2005 as a disease threat to endangered native fish Leucaspius delineatus and it caused a large increase in fish mortality [33]. In Turkey, the emergence of S. destruens was detected in 2017 and it associated with severe declines 
in endemic fish species in the wild [31]. In Manyas Lake, where small-scaled fishery is carried out on local fish species, it is thought that this invasive fish $P$. parva with a high deadly pathogen risk may have a negative effect on native and endemic fish populations.

In conclusion, for the future of the endemic and native fishes living in the Manyas Lake, risk assessment analyses are essential for these invasive species identified. According to IUCN Red List [34, 35], two endemic fish species living in the lake basin are classified as threatened; A. carinatus as Endangered (EN) and O. simavicus as Critically endangered (CR). Firstly, the population sizes of the endemic and native fishes should be determined and the changes over the years should be followed. Additionally, pathogen emergence, which is caused by $P$. parva, in the native fish populations should be investigated. These invasive fishes can be taken under biological control by the carnivorous fish species of the lake, E. lucius and S. glanis, and the waterfowls that put pressure on them. For this reason, prey-predator relationships should be revealed in the lake ecosystem. It is also pretty important to take the necessary precautions to prevent the existence of endemic and native fishes living in the lake from being threatened by invasive fish species.

\section{Acknowledgements}

This study was supported within the scope of the TÜBİTAK-1003 Project entitled "Development of an Integrated Ecosystem Modelling Based Decision Support System for Management of Manyas Lake Watershed" (No: 116Y406). We would like to thank Ali Özgen, who is the local fisherman, and Burak Kaynaroğlu for helping during the field surveys.

\section{References}

[1] Gozlan, R. E. (2008). Introduction of non-native freshwater fish: is it all bad? Fish and Fisheries, 9, 106-115. https://doi.org/10.1111/j.1467-2979.2007.00267.x

[2] Gozlan, R. E., Britton, J. R., Cowx, I. \& Copp, G. H. (2010). Current knowledge on non-native freshwater fish introductions. Journal of Fish Biology, 76, 751-786. https://doi.org/10.1111/j.1095-8649.2010.02566.x

[3] Tarkan, A. S. (2013). Introduction pathways, impacts and protection measures of non-native freshwater fishes in Turkey and the world. Istanbul University Journal of Fisheries Aquatic Sciences, 28, 63-104. (in Turkish).

[4] Courtenay, W. R. \& Moyle, P. B. (1992). Crimes against biodiversity - the lasting legacy of fish introductions. In: Transactions of the Fifty-Seventh North American Wildlife and Natural Resources Conference (ed R.E. McCabe). Wildlife Management Institute, Washington, pp. 365-372.

[5] Copp, G. H., Bianco, P. G., Bogutskaya, N. G., Erős, T., Falka, I., Ferreira, M. T., Fox, M. G., Freyhof, J., Gozlan, R. E., Grabowska, J., Kováč, V., Moreno-Amich, R., Naseka, A. M., Peňáz, M., Povž, M., Przybylski, M., Robillard, M., Russell, I. C., Stakénas, S., Šumer, S., Vila-Gispert, A. \& Wiesner, C. (2005). To be, or not to be, a non-native freshwater fish? Journal of Applied Ichthyology, 21, 242-262. https://doi.org/10.1111/j.1439-0426.2005.00690.x

[6] Ramler, D. \& Keckeis, H. (2019). Occurrence of non-native fishes in the Danube east of Vienna (Austria) and potential interactions of invasive gobiids with native fishes. Journal of Applied Ichthyology, 35, 850-862. https://doi.org/10.1111/jai.13916

[7] van Zwieten, P. A. M., Kolding, J., Plank, M. J., Hecky, R. E., Bridgeman, T. B., MacIntyre, S., Seehausen, O. \& Silsbe, G. M. (2016). The Nile perch invasion in Lake Victoria: cause or consequence of the haplochromine decline? Canadian Journal of Fisheries and Aquatic Sciences, 2016, 73(4), 622-643. https://doi.org/10.1139/cjfas-2015-0130

[8] Kitchell, J. F., Schindler, D. E., Ogutu-Ohwayo, R. \& Reinthal, P. N. (1997). The Nile perch in Lake Victoria: interactions between predation and fisheries. Ecological Applications, 7, 653-664. https://doi.org/10.1890/10510761(1997)007[0653:TNPILV]2.0.CO;2

[9] Arslan, N., Ulukütük, S. \& Mercan, D. (2018). Assessment of water quality in three sub-basins of Susurluk River (Northwest Anatolia) according to invertebrates and biotic indices. Biological Diversity and Conservation, 11 (3), 1-8.

[10] Yeniyurt, C. \& Hemmami, M. (2011). Ramsar sites of Turkey. Doğa Derneği Publications, Ankara, Turkey.

[11] Ar1, Y. (2019). Fisheries in Lake Manyas (Bal1kesir): Culture, ecology and sustainability. Aegean Geographical Journal, 28 (2), 179-198. (in Turkish)

[12] Kosswig, C. (1939). Faunengeschichte der Bosphorus Region. Cr. Ann. Et. Arch. Soc. Turquie Sci. Phys. Et. Nat. VII.

[13] Balık, S. \& Ustaoğlu, M. R. (1990). Kuş Gölü (Bandırma) sazan (Cyprinus carpio L., 1758) popülasyonunun biyo-ekolojik özelliklerinin incelenmesi. X. Ulusal Biyoloji Kongresi, 18-20 Temmuz 1990, Erzurum, Zooloji Bildirileri, 4, 271-282. (in Turkish)

[14] Turan, D., Berber, S., Topkara, E., T. \& Verep, B. A. (2005). First record (Knipowitschia longicaudata (Kessler, 1877)) for the fish fauna of Lake Manyas. Turkish Journal of Zoololgy, 29, 171-176.

[15] Turan, D., Ekmekçi, F. G., Kaya, C. \& Güçlü, S. S. (2013). Alburnoides manyasensis (Actinopterygii, Cyprinidae), a new species of cyprinid fish from Manyas Lake basin, Turkey. ZooKeys, 276, 85-102. https://doi.org/10.3897/zookeys.276.4107 
[16] Albay, M. \& Akçaalan, R. (2003). Comparative study of periphyton colonisation on common reed (Phragmites australis) and artificial substrate in a shallow lake, Manyas, Turkey. Hydrobiologia, 506-509, 531-540. https://doi.org/10.1023/B:HYDR.0000008606.69572.f6

[17] Dorak, Z., Köker, L., Sağlam, O., Akçaalan, R. \& Albay, M. (2017). Determination of zooplankton community structure, biomass and trophic state of a shallow turbid lake. Fresenius Environmental Bulletin, 26(1A), 834-845.

[18] Emiroğlu, Ö., Arslan, N., Malkoç, S., Koç, B. \& Çiçek, A. (2008). Determination of cadmium levels in lake water, sediment, meiobenthos (Chironomidae) and three fish species from Lake Uluabat (a Ramsar site in Turkey). EIFAC Occasional Paper, $44,263$.

[19] Crivelli, A. J. \& Boy, V. (1987). The diet of the mosquitofish Gambusia affinis (Baird \& Girard) (Poecilidae) in Mediterranean France. Revue D’Ecologie-La Terre Et La Vie, 42, 421-435.

[20] Singh, N. \& Gupta, P. K. (2010). Reproductive biology of eastern mosquito fish Gambusia holbrooki (Girard) (Poeciliiadae) in a sub-tropical Lake, Lake Nainital (India). International Journal of Current Microbiology and Applied Sciences, 3(4), 1931.

[21] García-Berthou, E. (1999). Food of introduced mosquitofish: Ontogenetic diet shift and prey selection. Journal of Fish Biology, 55, 135-147.

[22] Yankova, M. (2016). Alien invasive fish species in Bulgarian waters: An overview. International Journal of Fisheries and Aquatic Studies, 4(2), 282-290.

[23] Alcaraz, C. \& García-Berthou, E. (2007). Life history variation of invasive mosquitofish (Gambusia holbrooki) along a salinity gradient. Biological Conservation, 139, 83-92. https://doi.org/10.1016/j.biocon.2007.06.006

[24] Gkenas, C., Oikonomou, A., Economou, A., Kiosse, F. \& Leonardos, I. (2012). Life history pattern and feeding habits of the invasive mosquitofish, Gambusia holbrooki, in Lake Pamvotis (NW Greece). Journal of Biological Research-Thessaloniki, $17,121-136$.

[25] Global Invasive Species Database, 2019; http://www.iucngisd.org/gisd/ [accessed date: 25 October 2019]

[26] Hurlbert, S.H., Zedler, J. \& Fairbanks, D. (1972). Ecosystem alteration by mosquitofish (Gambusia affinis) predation. Science, 175, 639-641.

[27] Kats, L. B. \& Ferrer, R. P. (2003). Alien predators and amphibian declines: Review of two decades of science and the transition to conservation. Diversity and Distributions, 9, 99-110. https://doi.org/10.1046/j.1472-4642.2003.00013.x

[28] Rincón, P. A., Correas, A. M., Morcillo, F., Risueňo, P. \& Lobón-Cerviá, J. (2002). Interaction between the introduced eastern mosquitofish and two autochthonous Spanish toothcarps. Journal of Fish Biology, 61, 1560-1585. https://doi.org/10.1111/j.1095-8649.2002.tb02498.x

[29] Gozlan, R. E., Pinder, A. C. \& Shelley, J. (2002). Occurrence of the Asiatic cyprinid Pseudorasbora parva in England. Journal of Fish Biology, 61, 298-300. https://doi.org/10.1111/j.1095-8649.2002.tb01755.x

[30] Gozlan R. E., Andreou, D., Asaeda, T., Beyer, K., Bouhadad R., Burnard, D., Caiola, N., Cakic, P., Djikanovic, V., Esmaeili, H. R., Falka, I., Golicher, D., Harka, A., Jeney, G., Kováč, V., Musil, J., Nocita, A., Povz, M., Poulet, N., Virbickas, T., Wolter, C., Tarkan, A. S., Tricarico, E., Trichkova, T., Verreycken, H., Witkowski, A., Zhang, C., Zweimmueller, I. \& Britton, J. R. (2010). Pan-continental invasion of Pseudorasbora parva: towards a better understanding of freshwater fish invasions. Fish and Fisheries, 11, 315-340. https://doi.org/10.1111/j.1467-2979.2010.00361.x

[31] Ercan, D., Andreou, D., Sana, S., Öntaş, C., Baba, E., Top, N., Karakuş, U., Tarkan, A. S. \& Gozlan, R. E. (2015). Evidence of threat to European economy and biodiversity following the introduction of an alien pathogen on the fungal-animal boundary. Emerging Microbes \& Infections, 2015, 4, e52. https://doi.org/10.1038/emi.2015.52

[32] Sana, S., Hardouin, E. A., Gozlan, R. E., Ercan, D., Tarkan, A. S., Zhang, T. \& Andreou, D. (2017). Origin and invasion of the emerging infectious pathogen Sphaerothecum destruens. Emerging Microbes \& Infections, $6, \mathrm{e} 76$. https://doi.org/10.1038/emi.2017.64

[33] Gozlan R. E., St-Hilaire, S., Feist, S. W., Martin, P. \& Kent, M. L. (2005). Biodiversity: Disease threat to European fish. Nature, 435, 1046.

[34] Freyhof, J. (2014). Alburnus carinatus. The IUCN Red List of Threatened Species 2014: e.T19018407A19222763. https://dx.doi.org/10.2305/IUCN.UK.2014-1.RLTS.T19018407A19222763.en. [accessed date: 20 April 2020]

[35] Crivelli, A. J. (2006). Oxynoemacheilus simavica. The IUCN Red List of Threatened Species 2006: e.T61347A12465793. https://dx.doi.org/10.2305/IUCN.UK.2006.RLTS.T61347A12465793.en. [accessed date: 20 April 2020] 